\title{
Suicidal ideation and suicide attempt in a clinical sample of Mexican naval military
}

\author{
René Ocampo-Ortega, 'Annel Noely Portillo-Wong ${ }^{2}$
}

\begin{abstract}
Servicio de Salud Mental, Hospital Naval de Especialidades de Veracruz, Secretaría de Marina-Armada de México, Veracruz, México.

2 Escuela Médico Naval, Secretaría de Marina Armada de México, Ciudad de México, México.
\end{abstract}

Correspondence:

René Ocampo-Ortega

Hospital Naval de Especialidades de Veracruz.

General Figueroa 151,

Col. Centro,

91700, Veracruz, México.

Phone: $01229932-6479$, ext 290.

Email: drocort@gmail.com

Received: 29 January 2019

Accepted: 5 December 2019

Citation:

Ocampo-Ortega, R., \& Portillo-Wong,

A. N. (2020). Suicidal ideation and suicide attempt in a clinical sample of Mexican naval military. Salud Mental, 43(2), 57-63

DOI: 10.17711/SM.0185-3325.2020.009

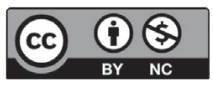

\begin{abstract}
Introduction. Suicide represents the sixteenth cause of death worldwide. Until a few years ago the suicide rate in the US military has been below that of the civilian population, but in 2008 the suicide rate among US soldiers began to outpace the civilian population. To our knowledge, there are no studies that describe suicidal behavior among Mexican military personnel. Objective. To know the frequency of suicidal ideation and suicide attempt in the last 12 months in Mexican naval military and determine the variables associated with both ideation and suicide attempt. Method. This cross-sectional study included 246 outpatients who were sent for psychiatric assessment from their operating units. A psychiatric interview was conducted using the diagnostic criteria of the International Classification of Diseases in its tenth edition, which included the presentation of suicidal ideation and attempted suicide in the last 12 months. Results. Suicidal ideation in the last 12 months occurred in 60 cases $(24.39 \%)$. Twenty-four cases $(9.76 \%)$ presented a suicide attempt in the last 12 months. Variables associated with suicidal ideation were military grade (seaman and classes, $p=.03$ ), suicide family history $(p<.01)$, depressive disorders $(p<.01)$, and personality disorders $(p<.01)$. Regarding the presentation of attempted suicide, the mean age in the cases was lower $(p<.01)$. There was also a higher frequency of attempted suicide in singles or without a couple $(p<.01)$, in personnel with four years or less in service $(p<.01)$, and in patients with a personality disorder $(p<.01)$. Discussion and conclusion. Greater emphasis in the detection of mental health problems, including suicidality among the military population and more representative studies at the national level are needed.
\end{abstract}

Keywords: Suicide, suicidal ideation, suicide attempt, risk factors, mental disorders, military.

\section{RESUMEN}

Introducción. El suicidio representa la decimosexta causa de muerte en todo el mundo. A partir del 2008, sabemos la tasa de suicidios en los soldados estadounidenses comenzó a superar a la de la población civil. Hasta donde sabemos no hay estudios que describan la conducta suicida en militares mexicanos. Objetivo. Estimar la frecuencia de la ideación suicida y el intento de suicidio en los últimos 12 meses en militares navales mexicanos y determinar las variables asociadas con la ideación y el intento de suicidio. Método. El estudio transversal incluyó 246 pacientes ambulatorios enviados para una evaluación psiquiátrica. Se realizó una entrevista psiquiátrica utilizando los criterios diagnósticos de la Clasificación Internacional de Enfermedades en su décima edición, que incluyó la presentación de ideación suicida e intento de suicidio en los últimos 12 meses. Resultados. La frecuencia en los últimos 12 meses de ideación suicida e intento de suicidio fue de $24.39 \%$ y $9.76 \%$, respectivamente. Las variables asociadas con la ideación suicida fueron: grado militar (clases y marinería, $p=.03)$, antecedente familiar de suicidio $(p<.01)$, diagnóstico de trastorno depresivo $(p<.01)$ y trastorno de la personalidad $(p<.01)$. En cuanto a la presentación del intento de suicidio, la edad media en los casos fue menor $(p<.01)$. Hubo una mayor frecuencia de intentos de suicidio en personas solteras o sin pareja $(p<.01)$, en personal con cuatro años o menos en servicio $(p<.01)$ y en pacientes con trastorno de personalidad $(p<.01)$. Discusión y conclusión. Se requiere un mayor énfasis en la detección de problemas de salud mental en la población militar y estudios más representativos a nivel nacional.

Palabras clave: Suicidio, ideación suicida, intento de suicidio, factores de riesgo, trastornos mentales, militares. 


\section{INTRODUCTION}

Suicide is a deliberate act in which a subject causes his/her death with knowledge or expectation of a fatal outcome. Attempted suicide is a non-fatal act of self-destruction often with the purpose of mobilizing aid (World Health Organization, 2000). Suicide represents the sixteenth cause of death worldwide (Olfson et al., 2017). In Mexico, suicide rate grew 275\% in the period between 1970 and 2007 (Borges, Orozco, Benjet, \& Medina-Mora, 2010). Until a few years ago, the suicide rate among the US military has been below the civilian population, but in 2008 the suicide rate in US soldiers began to outpace that of the civilian population and in certain years (2010 and 2011) mortality due to suicide exceeded mortality due to combat or accidents (Kuehn, 2009; Castro \& Kintzle, 2014; Nock et al., 2013).

In several studies and taking as a framework the Army Study to Assess Risk and Resilience in Servicemembers (STARSS), lifetime prevalence of suicidal ideation has been found to be between $13.9 \%$ and $14.1 \%$, suicide planning between $2.3 \%$, and $5.3 \%$ and suicide attempt between $1.9 \%$ and $2.4 \%$, with a suicide attempt rate of 377 per 100,000 person years in soldiers and 27.9 per 100,000 person years in officers (Nock et al., 2014; Ursano et al., 2015b; Ursano et al., 2017). The suicide rate in the US military has been estimated at 18.5 per 100,000 person-years, representing the second cause of death in this population (Schoenbaum et al., 2014).

Due to the increasing participation of the Mexican military in actions aimed at facing the risks and threats to preserve the integrity, stability, and permanence of the Mexican State (Diario Oficial de la Federación, 2013), it is considered necessary to know the impact of such actions on mental health of military personnel, and in particular, to understand the factors associated with suicidal risk. To our knowledge, there are no studies that describe suicidal behavior among Mexican military personnel. The aims of the present study are to know the frequency of suicidal ideation and suicide attempt in the last 12 months in Mexican naval military who attend assessment at the psychiatric service at the Hospital Naval de Veracruz and to determine the risk factors with both ideation and suicide attempt. We expect a greater proportion of suicidal ideation and suicide attempts in the military with the following variables as risk factors: young personnel, women, single marital status, low military rank, less than four years of service, family history of suicide, participation in combat, depressive disorders, and personality disorders.

\section{METHOD}

\section{Participants}

This cross-sectional study included a non-probabilistic sample of 246 outpatients who were sent for psychiatric as- sessment from their Operating Units to the Mental Health Service of the Hospital Naval de Especialidades de Veracruz, Mexico. The study was conducted in the period between January 2017 and June 2018.

\section{Measurements}

An unstructured psychiatric interview was conducted by a certified psychiatrist with 12 years of experience (R.O.O.), using the diagnostic criteria of the International Classification of Diseases in its tenth edition. In the present study, only the main diagnosis in the last 12 months was used. In the interview, sociodemographic variables and specific military variables were collected, such as military rank, time in service, and lifetime participation in combat or high impact operations. To assess suicide risk in the last 12 months, the questions "In the last year, have you thought you would be better dead, or have you wanted to be dead?," and "In the last year, have you tried to commit suicide?." In cases of suicide attempt the method was asked.

\section{Statistical analysis}

The study variables are presented as mean and standard deviations for the continuous ones and in frequencies and percentages for the categorical ones. The chi-square and Student's T-test were used to make comparisons of the study variables between the groups with suicidal ideation and without it ideation. The same was done with the group with attempted suicide and without such condition. Results were expressed as odds ratio (OR), 95\% confidence intervals, and nominal significant differences $(p \leq .05)$. Data were analyzed with the statistical package STATA 10.

\section{Ethical considerations}

This study was approved by the local Institutional Review Board (Act number 026/2016). The present study is based on the principles dictated by the Declaration of Helsinki and the National General Health Law and in the corresponding Research Regulation. The participants were informed that clinical attention would not be affected by any rejection of participation in the study. All the personnel invited to participate signed a written informed consent to participate in the study. The protection of data was regulated according to what is suggested by the Federal Institute of Access to Information in the document "Report on access to clinical files" published in 2004; section 7.2 "Processing data for research purposes," with the guarantee that the use of patient information would not diminish confidentiality. 


\section{RESULTS}

A total of $n=246$ naval military were sent to psychiatric assessment in the study period. No patient refused to participate in the study. The mental disorders and characteristics of the sample are described in Tables 1 and 2. The mean age of the military evaluated was 33.14 years $(S D=8.43)$.

The mental disorders most frequently diagnosed in the sample were depressive disorders $(n=48,20.51 \% ; 89.5 \%$ with mild to moderate severity), personality disorders $(n=41$, $17.52 \% ; 24.39 \%$ with full criteria and $63.41 \%$ without full criteria for borderline personality disorder), anxiety disorders $(n=32,13.68 \% ; 59.37 \%$ generalized anxiety disorder or unespecified), and post-traumatic stress disorder $(n=27$, $11.54 \%$ ) (Table 1). In twelve military no psychiatric diagnosis was made because they were incorrectly sent to assessment for non-clinical reasons (disciplinary aspects).

Suicidal ideation and suicide attempt in the last 12 months occurred in $n=60$ cases $(24.39 \%)$ and $n=24$ cases (9.76\%), respectively. All cases with suicide attempt had suicidal ideation before the act. The most frequent method was drug intoxication ( $n=10$ cases, $41.67 \%$ ), followed by forearm cuts ( $n=6$ cases, $25 \%$ ), and hanging ( $n=4$ cases, $16.67 \%$ ). One case presented a failed suicide attempt with a firearm and three cases used other methods, such as car crash or having been run over by a vehicle.

Military with lower military rank, suicide family history, depressive disorders, and personality disorders were at a greater risk for presenting suicidal ideation (Table 2). It was observed in young people, in singles, and in personnel exposed to combat a trend to present suicidal ideation

Table 1

Main psychiatric diagnosis in naval military (ICD-10)

\begin{tabular}{lcc}
\hline Mental disorder & $n$ & $\%$ \\
\hline Organic mental disorders & 15 & 6.41 \\
Substance use disorders & 11 & 4.7 \\
Psychotic disorders & 12 & 5.13 \\
Bipolar disorders & 10 & 4.27 \\
Depressive disorders & 48 & 20.51 \\
Anxiety disorders & 32 & 13.68 \\
Obsessive-compulsive disorder & 1 & .43 \\
Post-traumatic stress disorder & 27 & 11.54 \\
Adjustment disorders & 22 & 9.4 \\
Dissociative disorders & 2 & .85 \\
Somatoform disorders & 1 & .43 \\
Sleep disorders & 8 & 3.42 \\
Personality disorders & 41 & 17.52 \\
Impulse control disorders & 1 & .43 \\
Generalized developmental disorders & 1 & .43 \\
Other disorders & 2 & .85 \\
Total & $234^{*}$ & 100 \\
\hline
\end{tabular}

Note: ${ }^{\star} 12$ cases without psychiatric diagnosis. more frequently; however, differences were not statistically significant. The military with anxiety disorder had a significantly lower risk of presenting suicidal ideation, while in the military with post-traumatic stress disorder no risk for suicidal ideation was observed.

Regarding the presentation of attempted suicide, it was observed that the mean age in the cases was significantly lower than that of the military without attempt (28.2 years $v s$. 33.67 years, respectively, $t=-3.06, p<.01$ ). There was also a higher frequency of attempted suicide in singles or without a couple, in personnel with four years or less in service, and in patients with personality disorder. Contrary as expected, depression was not associated with a higher percentage of suicide attempts in the sample. In this sample, there were no cases of attempted suicide in the military with anxiety disorders or with post-traumatic stress disorder (Table 3 ).

\section{DISCUSSION AND CONCLUSION}

To our knowledge, this is the first study that describes suicidal behavior among Mexican military naval personnel. We found a 12-month frequency of suicidal ideation and attempted suicide of $24.39 \%$ and $9.76 \%$, respectively, higher than those reported in the US Army Study to Assess Risk and Resilience in Servicemembers (STARSS), 13.9\% - 14.1\% for suicidal ideation and $1.9 \%-2.4 \%$ for attempted suicide (Nock et al., 2014). However, it should be noted that the sample of the STARSS study included all the personnel in service, not only those sent to mental health service and suicidality was evaluated not only in the past 12-months but through life.

In the present study, greater risk for suicidal ideation and attempt were observed, specifically in young personnel (suicide attempt), in singles (suicide ideation and attempt), in Classes and Seaman (ideation), and in soldiers with four years or less in the service (suicide attempt). In our study, no gender differences were observed, possibly due to a lower proportion of women in the present study. It is consistently known that in females there are more suicide attempts than in men (Street et al., 2015; Brendel, Brezing, Lagomasino, Perlis, \& Stern, 2016). Except for gender, our data replicate previous reports in the literature (LeardMann et al., 2013; Drummet, Coleman, \& Cable, 2003; Nock et al., 2014; Ursano et al., 2015a; Reger et al., 2015), with greater risk of suicidal behavior in military under 29 years, in soldiers with less academic training, in the lower grades, in those with four or less years of service, and in those with a personal history of mental disorders, especially those who had been diagnosed in the previous month.

Personality disorders, particularly in the case of the emotionally unstable personality disorder, are widely associated with suicidal behavior (Hong, 2016; Moukaddam, Flores, Matorin, Hayden, \& Tucci, 2017). In the present study, personality disorders were consistently associated with both sui- 
Table 2

Variables associated with suicidal ideation in a clinical sample of Mexican Naval Military

\begin{tabular}{|c|c|c|c|c|c|}
\hline \multirow[b]{3}{*}{ Variable } & \multirow[b]{2}{*}{ Total sample } & \multicolumn{2}{|c|}{ Suicide Ideation } & \multirow[b]{3}{*}{$X^{2}$} & \multirow[b]{3}{*}{$p$} \\
\hline & & No & Yes & & \\
\hline & $N(\%)$ & $n(\%)$ & $n(\%)$ & & \\
\hline \multicolumn{6}{|l|}{ Gender } \\
\hline Female & $65(26.42)$ & $49(26.34)$ & $16(26.67)$ & .002 & .961 \\
\hline Male & 181 (73.58) & 137 (73.66) & $44(73.33)$ & \multicolumn{2}{|c|}{$\mathrm{OR}=1.01$} \\
\hline Total & $246(100)$ & $186(100)$ & $60(100)$ & \multicolumn{2}{|c|}{$\mathrm{Cl} 95 \%[.52,1.96]$} \\
\hline \multicolumn{6}{|l|}{ Marital status } \\
\hline Single/without a couple & $96(39.02)$ & $67(36.02)$ & $29(48.33)$ & 2.88 & .089 \\
\hline Married/with a couple & $150(60.98)$ & $119(63.98)$ & $31(51.67)$ & \multicolumn{2}{|c|}{$\mathrm{OR}=1.66$} \\
\hline Total & $246(100)$ & $186(100)$ & $60(100)$ & \multicolumn{2}{|c|}{$\mathrm{Cl} 95 \%[.92,2.99]$} \\
\hline \multicolumn{6}{|l|}{ Military rank } \\
\hline Seaman/Classes & $170(69.11)$ & 122 (65.59) & $48(80)$ & 4.41 & .036 \\
\hline Officers/Captains/Admirals & 76 (30.89) & 64 (34.41) & $12(20)$ & \multicolumn{2}{|c|}{$\mathrm{OR}=2.09$} \\
\hline Total & $246(100)$ & $186(100)$ & $60(100)$ & \multicolumn{2}{|c|}{$\mathrm{Cl} 95 \%[1.04,4.23]$} \\
\hline \multicolumn{6}{|l|}{ Time in service } \\
\hline 4 years or less & $57(23.17)$ & $40(21.51)$ & $17(28.33)$ & 1.18 & .276 \\
\hline More than 4 years & $189(76.83)$ & $146(78.49)$ & $43(71.67)$ & \multicolumn{2}{|c|}{$\mathrm{OR}=1.44$} \\
\hline Total & $246(100)$ & $186(100)$ & $60(100)$ & \multicolumn{2}{|c|}{$\mathrm{Cl} 95 \%[.74,2.79]$} \\
\hline \multicolumn{6}{|l|}{ Participation in combat } \\
\hline Yes & $51(20.73)$ & $34(18.28)$ & $17(28.33)$ & 2.79 & .095 \\
\hline No & 195 (79.27) & $152(81.72)$ & $43(71.67)$ & \multicolumn{2}{|c|}{$\mathrm{OR}=1.76$} \\
\hline Total & $246(100)$ & $186(100)$ & $60(100)$ & \multicolumn{2}{|c|}{$\mathrm{Cl} 95 \%[.90,3.46]$} \\
\hline \multicolumn{6}{|l|}{ Suicide family history } \\
\hline Yes & $10(4.07)$ & $2(1.08)$ & $8(13.33)$ & 17.47 & $<.01$ \\
\hline No & 236 (95.93) & 184 (98.92) & $52(86.67)$ & \multicolumn{2}{|c|}{$O R=14.15$} \\
\hline Total & $246(100)$ & $186(100)$ & $60(100)$ & \multicolumn{2}{|c|}{$\mathrm{Cl} 95 \%[2.91,68.69]$} \\
\hline \multicolumn{6}{|l|}{ Depressive disorder } \\
\hline Yes & $48(20.51)$ & $32(18.39)$ & $16(26.67)$ & 7.58 & $<.01$ \\
\hline No & $186(79.49)$ & 142 (81.61) & 44 (73.33) & \multicolumn{2}{|c|}{$\mathrm{OR}=2.95$} \\
\hline Total & $234(100)$ & $174(100)$ & $60(100)$ & $\mathrm{Cl} 95 \%$ & $3,6.29]$ \\
\hline Anxiety disorder & & & & & \\
\hline Yes & $32(13.68)$ & $30(17.24)$ & $2(3.33)$ & 7.31 & $<.01$ \\
\hline No & 202 (86.32) & $144(82.76)$ & $58(96.67)$ & & \\
\hline Total & $234(100)$ & $174(100)$ & $60(100)$ & $\mathrm{Cl} 95$ & $3, .71]$ \\
\hline Postraumatic stress disorder & & & & & \\
\hline Yes & $27(11.54)$ & $21(12.07)$ & $6(10)$ & .18 & .665 \\
\hline No & $207(88.46)$ & $153(87.93)$ & $54(90)$ & & \\
\hline Total & $234(100)$ & $174(100)$ & $60(100)$ & $\mathrm{Cl} 95^{\circ}$ & , 2.11] \\
\hline Personality disorder & & & & & \\
\hline Yes & $41(17.52)$ & $18(10.34)$ & $23(38.33)$ & 24.18 & $<.01$ \\
\hline No & $193(82.48)$ & $156(89.66)$ & $37(61.67)$ & & \\
\hline Total & $234(100)$ & $174(100)$ & $60(100)$ & $\mathrm{Cl} 95 \%$ & $9,6.31]$ \\
\hline
\end{tabular}

Notes: $\mathrm{OR}=$ odds ratio; $95 \% \mathrm{Cl}=95 \%$ confidence interval.

cidal ideation and suicide attempts. Although the STARSS study did not include the diagnosis of personality disorders, the authors of the study emphasize that disorders associated with problems of aggressiveness/impulsivity can increase suicide risk independently or in comorbidity with other disorders (Nock et al., 2013). Patients with personality disorders such as emotionally unstable and dissocial often present af- fective instability and make impulsive suicidal threats or attempts; these attempts may become progressively more lethal if they are not taken seriously (Blais, Smallwood, Groves, Rivas-Vazquez, \& Hopwood, 2016). It is possible that high levels of stress generate a greater suicide risk in these patients, even without fulfilling all the criteria necessary to make an specific diagnosis (unspecified disorders) (Nock et al., 2013; 
Table 3

Variables associated with suicide attempt in a clinical sample of Mexican Naval Military

\begin{tabular}{|c|c|c|c|c|c|c|c|}
\hline \multirow[b]{3}{*}{ Variable } & \multirow[b]{2}{*}{ Total sample } & \multicolumn{4}{|c|}{ Suicide attempt } & \multirow[b]{3}{*}{$X^{2}$} & \multirow[b]{3}{*}{$p$} \\
\hline & & & No & & Yes & & \\
\hline & $N(\%)$ & & $n(\%)$ & & $n(\%)$ & & \\
\hline \multicolumn{8}{|l|}{ Gender } \\
\hline Female & $65(26.42)$ & 57 & $(25.68)$ & 8 & (33.33) & .653 & .41 \\
\hline Male & $181(73.58)$ & 165 & $(74.32)$ & 16 & $(66.67)$ & \multicolumn{2}{|c|}{$\mathrm{OR}=1.44$} \\
\hline Total & $246(100)$ & 222 & $(100)$ & 24 & $(100)$ & \multicolumn{2}{|c|}{$\mathrm{Cl} 95 \%[.58,3.56]$} \\
\hline \multicolumn{8}{|l|}{ Marital status } \\
\hline Single/without a couple & $96(39.02)$ & 80 & $(36.04)$ & 16 & $(66.67)$ & 8.53 & $<.01$ \\
\hline Married/with a couple & $150(60.98)$ & 142 & $(63.96)$ & 8 & (33.33) & \multicolumn{2}{|c|}{$\mathrm{OR}=3.55$} \\
\hline Total & $246(100)$ & 222 & $(100)$ & 24 & $(100)$ & \multicolumn{2}{|c|}{$\mathrm{Cl} 95 \%[1.45,8.66]$} \\
\hline \multicolumn{8}{|l|}{ Military rank } \\
\hline Seaman/Classes & $170(69.11)$ & 151 & $(68.02)$ & 19 & $(79.17)$ & 1.26 & .261 \\
\hline Officers/Captains/Admirals & 76 (30.89) & 71 & $(31.98)$ & 5 & $(20.83)$ & \multicolumn{2}{|c|}{$\mathrm{OR}=1.78$} \\
\hline Total & $246(100)$ & 222 & $(100)$ & 24 & $(100)$ & \multicolumn{2}{|c|}{$\mathrm{Cl} 95 \%[.64,4.97]$} \\
\hline \multicolumn{8}{|l|}{ Time in service } \\
\hline 4 years or less & $57(23.17)$ & 46 & $(20.72)$ & 11 & $(45.83)$ & 7.67 & $<.01$ \\
\hline More than 4 years & $189(76.83)$ & 176 & $(79.28)$ & 13 & $(54.17)$ & \multicolumn{2}{|c|}{$\mathrm{OR}=3.23$} \\
\hline Total & $246(100)$ & 222 & $(100)$ & 24 & $(100)$ & \multicolumn{2}{|c|}{ Cl 95\% $[1.36,7.69]$} \\
\hline \multicolumn{8}{|l|}{ Participation in combat } \\
\hline Yes & $51(20.73)$ & 46 & $(20.72)$ & 5 & $(20.83)$ & .00 & .99 \\
\hline No & 195 (79.27) & 176 & $(79.28)$ & 19 & $(79.17)$ & \multicolumn{2}{|c|}{$\mathrm{OR}=1.00$} \\
\hline Total & $246(100)$ & 222 & $(100)$ & 24 & $(100)$ & \multicolumn{2}{|c|}{$\mathrm{Cl} 95 \%[.35,2.84]$} \\
\hline \multicolumn{8}{|l|}{ Suicide family history } \\
\hline Yes & $10(4.07)$ & 8 & $(3.60)$ & 2 & $(8.33)$ & 1.24 & .26 \\
\hline No & 236 (95.93) & 214 & $(96.40)$ & 22 & $(91.67)$ & \multicolumn{2}{|c|}{$\mathrm{OR}=2.43$} \\
\hline Total & $246(100)$ & 222 & $(100)$ & 24 & $(100)$ & \multicolumn{2}{|c|}{$\mathrm{Cl} 95 \%[.48,12.17]$} \\
\hline \multicolumn{8}{|l|}{ Depressive disorder } \\
\hline Yes & $48(20.51)$ & 43 & $(20.48)$ & 5 & $(20.83)$ & .001 & .96 \\
\hline No & $186(79.49)$ & 167 & $(79.52)$ & 19 & $(79.17)$ & & 3.25 \\
\hline Total & $234(100)$ & 210 & $(100)$ & 24 & $(100)$ & IC 95\% & $9,11.77]$ \\
\hline Anxiety disorder & & & & & & & \\
\hline Yes & $32(13.68)$ & 32 & $(15.24)$ & 0 & $(0)$ & 4.23 & .04 \\
\hline No & $202(86.32)$ & 178 & $(84.76)$ & 24 & $(100)$ & & \\
\hline Total & $234(100)$ & 210 & $(100)$ & 24 & $(100)$ & & $\%$--- \\
\hline Postraumatic stress disorder & & & & & & & \\
\hline Yes & $27(11.54)$ & 27 & $(12.86)$ & 0 & $(0)$ & 3.48 & .06 \\
\hline No & $207(88.46)$ & 183 & $(87.14)$ & 24 & $(100)$ & & \\
\hline Total & $234(100)$ & 210 & $(100)$ & 24 & $(100)$ & & $\%$--- \\
\hline Personality disorder & & & & & & & \\
\hline Yes & $41(17.52)$ & 27 & $(12.86)$ & 14 & $(58.33)$ & 30.82 & $<.01$ \\
\hline No & $193(82.48)$ & 183 & $(87.14)$ & 41 & $(41.67)$ & OR & 4.51 \\
\hline Total & $234(100)$ & 210 & $(100)$ & 24 & $(100)$ & $\mathrm{Cl} 95 \%$ & $32,43.66]$ \\
\hline
\end{tabular}

Notes: $\mathrm{OR}=$ odds ratio; $95 \% \mathrm{Cl}=95 \%$ confidence interval.

Hawton, Houston, Haw, Townsend, \& Harris, 2003; Boden, Babdon, Vujanovic, Short, \& Bon-Miller, 2013).

In the present study, a greater proportion of suicidal ideation was observed in patients with depressive disorders but, unlike to what was expected, we did not observe a statistically significant association in the presentation of suicide attempts in soldiers with depressive disorders. This negative result could have been secondary to the low frequency of suicide attempt cases. Due to the above, it is possible that the transition from ideation to attempted suicide in these patients could have been interrupted by receiving early and adequate treatment. In relation to suicidal ideation, a lower risk was observed in the study in the military with anxiety disorders; however, the small number of cases $(n=2)$ does 
not allow for definitive conclusions, and the same is true for the military with post-traumatic stress disorder.

The results of the present study cannot be generalized to the rest of the Mexican naval military because it was a clinical sample, overrepresented by men, with a low military grade, and with administrative or naval health functions. Another limitations of the study are that a structured interview was not applied and mental health problems may go undiagnosed because it has been reported in the literature that military personnel do not perceive a need for treatment or do not seek help (Naifeh et al., 2016). During general practitioner evaluations, military personal with mental health problems are not regularly assessed (West et al., 2014; Hoge et al., 2004); do not report symptoms during high impact operations (Bliese, Wright, Adler, Thomas, \& Hoge, 2007); or are screened as positives but do not follow up on the referral (Burnam, Meredith, Tanielian, \& Jaycox, 2009; Hoge et al., 2014). Similarly, the presentation of substance use disorders and psychiatric comorbidity were not analyzed. These variables should be included in future studies.

Ensuring adequate functioning of programs to facilitate detection and treatment is essential and may be aided by improving mental health knowledge among military personnel and maximizing a culture of honest symptom reporting (Warner et al., 2011; Thomas, Adrian, Penix, Wilk, \& Adler, 2016). Detection may be enhanced nationwide through expanded mental health screening in primary care and timely reference to the naval psychiatry services available in Mexico. Screening before basic training would benefit new soldiers because many enter the armed forces with a history of mental health problems and suicide ideation (Ursano et al., 2015a; Rosellini et al., 2014; Ursano et al., 2018). Finally, the information generated from the screening programs can generate future studies that determine risk factors among the naval military nationwide.

In conclusion, we observed increased OR for suicidal ideation and suicide attempt in Mexican naval personnel in clinical practice, particularly in young people, with less experience in the military field (lower military grades, four years or less in service), with a family history of suicide, and with depressive or personality disorders. Greater emphasis in the detection of mental health problems in the military population and more representative studies at the national level are needed.

\section{Funding}

None.

\section{Conflict of interests}

The authors declare they have no conflicts of interest.

\section{Acknowledgments}

The authors thank the Secretaría de México of Mexico and the director of the Hospital Naval de Veracruz for facilitating the completion of this study.

\section{REFERENCES}

Blais, M. A., Smallwood, P., Groves, J. E., Rivas-Vazquez, R. A., \& Hopwood, C. J. (2016). Personality and Personality Disorders. In Stern, T. A., Fava, M., Wilens, T. E., \& Rosenbaum, J. F. (Eds.) Massachusetts General Hospital Comprehensive Clinical Psychiatry, (pp. 433-444). Boston, Massachusetts: Elsevier. ISBN: 9780323295079

Bliese, P. D., Wright, K. M., Adler, A. B., Thomas, J. L., \& Hoge, C. W. (2007). Timing of postcombat mental health assessments. Psychological Services, 4(3), 141-148. doi: 10.1037/1541-1559.4.3.141

Boden, M. T., Babdon, K. A., Vujanovic, A. A., Short, N. A., \& Bon-Miller, M. O. (2013). Posttraumatic stress disorder and cannabis use characteristics among military veterans with cannabis dependence. The American Journal on Addictions, 22(3), 277-284. doi: 10.1111/j.1521-0391.2012.12018.x

Borges, G., Orozco R., Benjet, C., \& Medina-Mora, M. E. (2010). Suicidio y conductas suicidas en México: retrospectiva y situación actual. Salud Pública de México, 52(4), 292-304.

Brendel, R. W., Brezing, C. A., Lagomasino, I. T., Perlis R. H., \& Stern, T. A. (2016). The Suicidal Patient. In Stern, T. A., Fava, M., Wilens, T. E., \& Rosenbaum, J. F. (Eds.) Massachusetts General Hospital Comprehensive Clinical Psychiatry, (pp. 589-598). Boston, Massachusetts: Elsevier. ISBN: 9780323295079

Burnam, M. A., Meredith, L. S., Tanielian, T., \& Jaycox, L. H. (2009). Mental health care for Iraq and Afghanistan war veterans. Health Affairs, 28(3), 771-782. doi: 10.1377/hlthaff.28.3.771

Castro, C. A., \& Kintzle, S. (2014). Suicides in the military: The post-modern combat veteran and the Hemingway effect. Current Psychiatry Reports, 16(8), 460. doi: 10.1007/s11920-014-0460-1

Diario Oficial de la Federación. (2013). Programa Sectorial de Marina 2013-2018. Retrieved from: http://www.dof.gob.mx/nota_detalle.php?codigo $=5326470 \& \mathrm{fe}$ cha $=16 / 12 / 2013$

Drummet, A. R., Coleman, M., \& Cable, S. (2003). Military families under stress: Implications for family life education. Family Relations, 52(3), 279-287. doi: 10.1111/j.1741-3729.2003.00279.x

Hawton, K., Houston, K., Haw, C., Townsend, E., \& Harris, L. (2003). Comorbidity of axis I and axis II disorders in patients who attempted suicide. American Journal of Psychiatry, 160(8), 1494-1500. doi: 10.1176/appi.ajp.160.8.1494

Hoge, C. W., Castro, C. A., Messer, S. C., McGurk, D., Cotting, D. I., \& Koffman, R. L. (2004). Combat duty in Iraq and Afghanistan, mental health problems, and barriers to care. The New England Journal of Medicine, 351(1), 13-22. doi: 10.1056/NEJMoa040603

Hoge, C. W., Grossman, S. H., Auchterlonie, J. L., Riviere, L. A., Milliken, C. S., \& Wilk, J. E. (2014). PTSD treatment for soldiers after combat deployment: Low utilization of mental health care and reasons for dropout. Psychiatric Services, 65(8), 997-1004. doi: 10.1176/appi.ps.201300307

Hong, V. (2016). Borderline personality disorder in the emergency department: good psychiatric management. Harvard Review Psychiatry, 24(5), 357-366. doi: 10.1097/HRP.0000000000000112

Kuehn, B. M. (2009). Soldier suicide rates continue to rise: military, scientists work to stem the tide. JAMA, 301(11), 1111-1113. doi: 10.1001/jama.2009.342

LeardMann, C. A., Powell, T. M., Smith, T. C., Bell, M. R., Smith, B., Boyko, E. J., ... Hoge, C. W. (2013). Risk factors associated with suicide in current and former US military personnel. JAMA, 310(5), 496-506. doi: 10.1001/jama.2013.65164

Moukaddam, N., Flores, A., Matorin, A., Hayden, N., \& Tucci, V. T. (2017). Difficult patients in the emergency department, personality disorders and beyond. Psychiatric Clinics of North America, 40(3), 379-395. doi: 10.1016/j. psc.2017.05.005

Naifeh, J. A., Colpe, L. J., Aliaga, P. A., Sampson N. A., Heeringa S. G., Stein M. B., ... Kessler, R. C. (2016). Barriers to initiating and continuing mental health treatment among soldiers in the Army Study to Assess Risk and Resilience in Servicemembers (Army STARRS). Military Medicine, 181(9), 1021-1032. doi: 10.7205/MILMED-D-15-00211

Nock, M. K., Deming, C. A., Fullerton, C. S., Gilman, S. E., Goldenberg, M., Kessler, R.C., ... Ursano, R. J. (2013). Suicide among soldiers: A review of psychosocial risk and protective factors. Psychiatry: Interpersonal \& Biological Processes, 76(2), 97-125. doi: 10.1521/psyc.2013.76.2.97 
Nock, M. K., Stein, M. B., Heeringa, S. G., Ursano, R. J., Colpe, L. J., Fullerton, C. S., ... Kessler, R. C. (2014). Prevalence and correlates of suicidal behavior among soldiers: Results from the Army Study to Assess Risk and Resilience in Servicemembers (Army STARRS). JAMA Psychiatry, 71(5), 514-22. doi: 10.1001/jamapsychiatry.2014.30

Olfson, M., Blanco, C., Wall, M., Liu, S., Saha, T. D., Pickering, R. P., \& Grant, B. F. (2017). National trends in suicide attempts among adults in the United States. JAMA Psychiatry, 74(11), 1095-1103. doi: 10.1001/jamapsychiatry.2017.2582

Reger, M. A., Smolenski, D. J., Skopp, N. A., Metzger-Abamukang, M. J., Kang, H. K., Bullman, T. A., ... Gahm, G. A. (2015). Risk of suicide among US military service members following Operation Enduring Freedom or Operation Iraqi Freedom deployment and separation from the US Military. JAMA Psychiatry, 72(6), 561-569. doi: 10.1001/jamapsychiatry.2014.3195

Rosellini, A. J., Heeringa, S. G., Stein, M. B., Ursano, R. J., Chiu, W. T., Colpe, L. J., ... Kessler R. C. (2014). Lifetime prevalence of DSM-IV mental disorders among new soldiers in the U.S. Army: results from the Army Study to Assess Risk and Resilience in Servicemembers (Army STARRS). Depression and Anxiety, 32(1), 13-24. doi: 10.1002/da.22316

Schoenbaum, M., Kessler, R. C., Gilman, S. E., Colpe, L. J., Heeringa, S. G., Stein, M. B., ... Cox, K. L. (2014). Predictors of suicide and accident death in the Army Study to Assess Risk and Resilience in Servicemembers (Army STARRS): Results from the Army Study to Assess Risk and Resilience in Servicemembers (Army STARRS). JAMA Psychiatry, 71(5), 493-503. doi: 10.1001/jamapsychiatry.2013.4417

Street, A. E., Gilman, S. E., Rosellini, A. J., Stein, M. B., Bromet, E. J., Cox, K. L., ,.. Kessler R. C. (2015). Understanding the elevated suicide risk of female soldiers during deployments. Psychological Medicine, 45(4), 717-726. doi: 10.1017/ S003329171400258X

Thomas, J. L., Adrian, A. L., Penix, E. A., Wilk, J. E., \& Adler A. B. (2016). Mental health literacy in U.S. soldiers: Knowledge of services and processes in the utilization of military mental health care. Military Behavioral Health, 4(2), 9299. doi: $10.1080 / 21635781.2016 .1153541$
Ursano, R. J., Heeringa, S. G., Stein, M. B., Jain, S., Raman, R., Sun, X., ... Kessler, R C. (2015a). Prevalence and correlates of suicidal behavior among new soldiers in the US Army: results from the Army Study to Assess Risk and Resilience in Servicemembers (Army STARRS). Depression and Anxiety, 32(1), 3-12. doi: 10.1002/da.22317

Ursano, R. J., Kessler, R. C., Stein, M. B., Naifeh, J. A., Aliaga, P. A., Fullerton, C. S., ... Heeringa, S. G. (2015b). Suicide attempts in the US Army during the wars in Afghanistan and Iraq, 2004 to 2009. JAMA Psychiatry, 72(9), 917-926. doi: 10.1001/jamapsychiatry.2015.0987

Ursano, R. J., Kessler, R. C., Naifeh, J. A., Herberman-Mash, H., Fullerton, C. S., Bliese, P. D., ... Stein, M. B. (2017). Risk of suicide attempt among soldiers in army units with a history of suicide attempts. JAMA Psychiatry, 74(9), 924-931. doi: 10.1001/jamapsychiatry.2017.1925

Ursano, R. J., Kessler, R. C., Naifeh, J. A., Herberman Mash, H., Nock, M. K., Aliaga, P. A., ... Stein, M. B. (2018). Risk factors associated with attempted suicide among US Army soldiers without a history of mental health diagnosis. JAMA Psychiatry, 75(10), 1022-1032. doi: 10.1001/jamapsychiatry.2018.2069

Warner, C. H., Appenzeller, G. N., Grieger, T., Belenkiy, S., Breitbach, J., Parker, J., ... Hoge, C. (2011). Importance of anonymity to encourage honest reporting in mental health screening after combat deployment. Archives of General Psychiatry, 68(10), 1065-1071. doi: 10.1001/archgenpsychiatry.2011.112

West, J. C., Wilk, J. E., Duffy, F. F., Kuramoto, S. J., Rae, D. S., Mościcki, E. K., \& Hoge, C. W. (2014). Mental health treatment access and quality in the Army: Survey of mental health clinicians. Journal of Psychiatric Practice, 20(6), 448459. doi: 10.1097/01.pra.0000456593.58739.61

World Health Organization. (2000). Preventing suicide. A resource for general physicians. (No. WHO/MNH/MBD/00.1). World Health Organization. Retrieved from: http://apps.who.int/iris/bitstream/handle/10665/67165/WHO MNH MB D_00.1.pdf; jsessionid $=3018$ B0C24765A54318B973E81920A528? sequence $=1$ 